\title{
The role of dyadic interactions between CEOs, chairs and owners in family firm governance
}

\author{
Hanna Maria Sievinen ${ }^{1}$ (D) Tuuli Ikäheimonen $^{1}$ (D) Timo Pihkala $^{1}$ (D)
}

Accepted: 22 December 2020 / Published online: 12 January 2021

(c) The Author(s) 2021

\begin{abstract}
The objective of this case-based study is to understand how the dyadic interaction between the key governance actors can influence the decision-making aimed at directing and controlling a family firm. The study provides evidence that dyadic interaction at the back stage of the formal governance process can offer a privileged position for the family firm owners who serve on the board, and the nonfamily member Chair of the Board, to influence decision-making before, after and between board meetings. The cases studied suggest that dyadic interactions can serve as preparation for formal board processes and complement and clarify them, yet they also have the potential to conflict with them. Dyadic interaction is also shown to offer important relational and emotional benefits that may not necessarily be achieved through larger group interaction. The findings suggest that although the actors can self-regulate their behaviour through informal rules, the rules may imperfectly address one risk of dyadic interaction - the reduced cognitive conflict among the board.
\end{abstract}

Keywords Corporate governance $\cdot$ Board of directors $\cdot$ Decision-making $\cdot$ Dyadic interaction · Family firm

\section{Introduction}

Literature and research have long emphasised formal governance mechanisms as means to direct and control firms. They largely originate from the legal systems in which firms operate (Chrisman et al. 2018). However, informal governance processes that exist alongside formal ones-reflecting the interests of the stakeholders, along with pressures for conformance and adaptation to the norms (Chrisman et al. 2018) — also play a role in a firm's decision-making (Astrachan 2010; Chrisman et al. 2018; Huse 2005). The heterogeneity of governance models

Hanna Maria Sievinen

hanna.sievinen@gmail.com

1 LUT University (Lappeenranta University of Technology), Lappeenranta, Finland 
(Daspit et al. 2018) and the informality of processes (e.g., Astrachan 2010; Canterino et al. 2013; Cater and Schwab 2008; Chrisman et al. 2018; Gersick et al. 1997) are family firm characteristics that are well recognised by scholars. This suggests that informal processes may play a particularly important role in family firm governance.

Enacting board roles is not restricted to the boardroom (Bezemer et al. 2018; Gabrielsson and Huse 2002; Huse 1998, 2005, 2007; Huse and Zattoni 2008; McNulty and Pettigrew 1999; McNulty et al. 2011; Pettigrew and McNulty 1995). Recent studies on family or entrepreneurial firms have highlighted the role of dyadic (one-to-one) interactions between board members and the CEO and shown how these roles are enacted at the firm governance. Examples such as those given by Garg and Eisenhardt (2017) and Sievinen et al. (2019, 2020b) provide micro-level evidence that before the board makes decisions as a coalition, interactions between the individual board members and the CEO influencing the decision have taken place outside the boardroom. Such dyadic encounters between individuals have been conceptualised as fundamental units of interpersonal interactions (Kenny et al., 2006), and selected studies on corporate governance related meetings suggest that dyadic interaction has distinct dynamics compared to larger group interactions (e.g., Imam and Spence 2016; Johed and Catasús 2018; Solomon and Darby 2005; Solomon et al. 2013).

An extensive body of research highlights the importance of the CEO-chair relationship (e.g., Koskinen and Lämsä 2016, 2017; McNulty et al. 2011). Earlier studies on family firm governance have also suggested that, apart from the CEO and the chair, the owners serving on the board are powerful brokers in family firm governance and their relations to non-family executives and board members can play a significant role (e.g., Johannisson and Huse 2000; Sievinen et al. 2020a, b). However, despite these findings and the recognition of the importance of informal processes in family firms, the role of the dyadic relations in family firm governance has only been studied to a limited extent. We have little empirical evidence of dyadic interaction at the back-stage of the formal governance of family firms and few, if any, conceptualisations to help to understand the role of this phenomenon in family firm decision-making. We also have limited knowledge on why the key governance actors of family firms engage in dyadic interaction, how these interactions are conducted, and what implications they can have on the decision-making in family firms. We argue that a case-based approach utilising highly granular data on family firms could help explore the dynamics of these behaviours and to understand their potential influence on family firm governance.

In our study we focus on an informal process of family firm governance, the dyadic interaction of key governance actors of a family firm, the CEO, the chair and the owners, that takes place back-stage (see e.g. Graaf 2018; Johed and Catasús 2018; Solomon et al. 2013), in contrast to the front-stage group interaction of the formal board meetings. Figure 1 below illustrates the focal dyadic relationships of this study.

The research question of our study is how do the dyadic interactions between the non-family CEO, the non-family chair and the owners who serve on the board (hereafter 'the owners') influence the decision-making aimed at directing and controlling 


\section{Focal dyadic relations of this study}

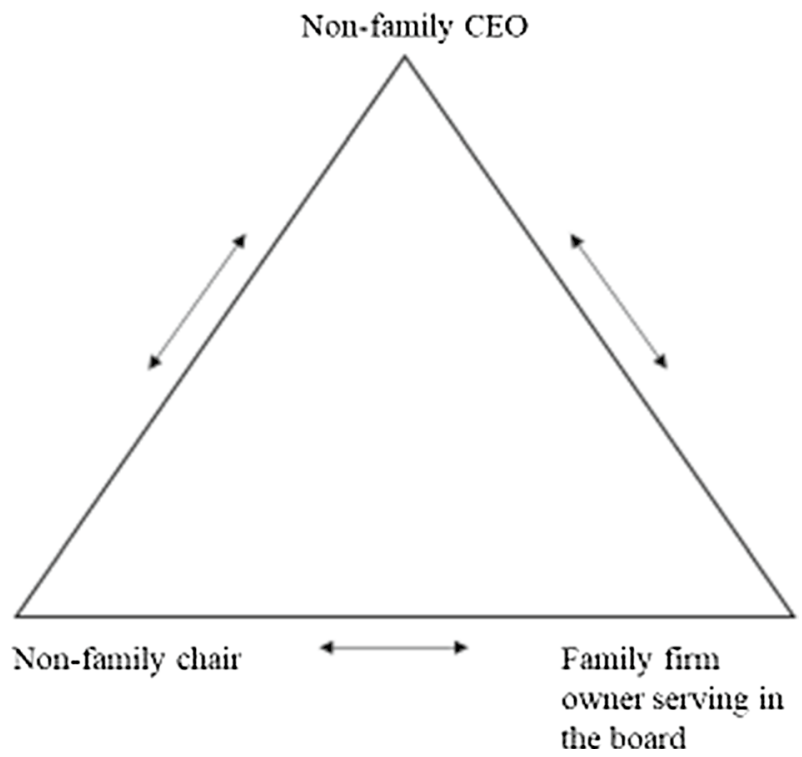

Fig. 1 Focal dyadic relations of this study

a family firm? Fig. 2 below illustrates the focus of this study and provides the key definitions adopted.

With our focus on the micro-level processes of two Finnish, later-generation (no longer managed or governed by the founder but by his or her descendants)

Focus and key definitions of this study on family firm ${ }^{1}$ corporate governance?

\begin{tabular}{|l|l|l|l|}
\hline Process: & Instead of formal & Informal & \\
\hline Space: & Instead of front-stage & Back-stage & \\
\hline & & $\begin{array}{l}\text { Influence on } \\
\text { family firm } \\
\text { corporate } \\
\text { governance? }\end{array}$ \\
\hline Form of interaction: & Instead of group & Dyadic $^{7}$ & \\
\hline
\end{tabular}

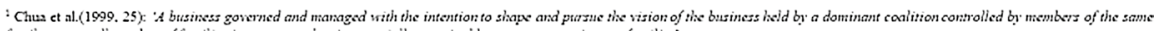
fanily or a smali nomber of families in a menser that is potentially sustainable across generations or families

Codbury Report. 1992.2.5)

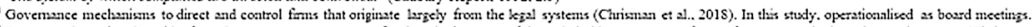

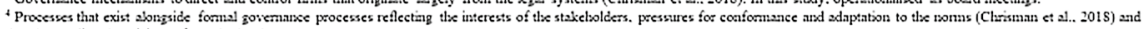
that do not directiy originatc from the $\mathrm{k} g_{\mathrm{g}} \mathrm{s}$ systems

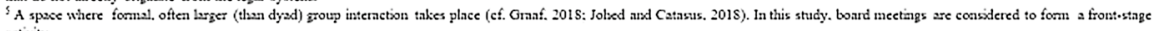
activity.

'A more private (when compared to froatestage) space where less formal, potentially dyadis interaction teles place as preperatioas for larger. more formal. group interaction at the front.

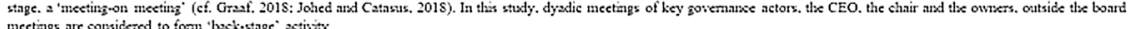
imetings are considered to forn 'bosk-stage' astivity

Fig. 2 Focus and key definitions of this study on family firm corporate governance 
family firms where the family primarily participates in business through serving on the board, we intend to answer our research question. Both case companies are attempting a strategic renewal; hence they are experiencing intense board involvement.

While a case-based study has limitations in terms of generalisation, we believe that our deep access to granular data reveals behavioural patterns that provide important insights on family firm governance. First, our data provide micro-level evidence of how dyadic interaction at the back-stage can offer the chair and the owners a privileged position to influence the decision-making before, between and after front-stage board meetings. We build on the previous studies on informal governance processes (Astrachan 2010; Chrisman et al. 2018; McNulty and Pettigrew 1999; Mustakallio et al. 2002) and the role of dyadic interaction between the top management team ('TMT') and the board members (Gabrielsson and Huse 2002; Garg and Eisenhardt 2017; McNulty and Pettigrew 1999; Sievinen et al. 2019, 2020b; Westphal and Stern 2006; Westphal and Zajac 1995) by providing an important process component for understanding family firm governance. Based on our case studies, we show that dyadic interaction can serve many purposes, as it is used for preparing for the board meetings, along with complementing them and clarifying decisions made.

Second, we propose that dyadic interaction at the back-stage can influence the board decision-making. To avoid negative influence at the back-stage dyadic interaction (namely, breaking the rules considered to define 'good governance'), the actors are shown to self-regulate their back-stage behaviour through informal rules. Dyadic interaction can have a positive influence through reducing information asymmetry between the actors and through offering a setting for back-stage interaction that is free from the pressures experienced in the boardroom. However, our study also reveals a new potential source of reduced cognitive conflict which is a recognised factor for decision-making inefficiencies (Barroso-Castro et al. 2017; Finkelstein and Mooney 2003; Forbes and Milliken 1999): dyadic interaction can align the views of a subset of the board or reduce the number of options presented before it as a coalition has the opportunity to discuss issues and make decisions. As a result, the CEO's proposals to the board and the latter's decisions can remain within 'Overton's window' (i.e., within what the owners or the chair consider acceptable options). The informal rules we observed in our case studies did not address this risk.

Third, our findings indicate that dyadic interactions may provide relational and emotional benefits that may not necessarily be achieved through larger group interactions. Our data suggests that it is not only important who participates in the dyadic interaction but also who does not. Dyadic interaction may offer key governance actors of a family firm a platform for playing multiple roles in a more versatile ways than a larger group interaction in a formal board meeting. Emotions and familyrelated or personal matters may be viewed as 'disruptions' that should principally be handled outside formal meetings. The results of our study therefore build on earlier findings about the back-stage interaction as a way to smooth out interaction at frontstage meetings (Graaf 2018; Johed and Catasús 2018). As such, these results provide new insights on the role of the dyadic relations of key family firm governance actors as 'meetings on meetings'. 


\section{Family firms, informal governance process, and governance-related meetings}

Our study delineates three different directions on research, informal governance processes and board dyadic interaction, as well as on meetings related to corporate governance.

\subsection{Informal governance processes in family firms}

The Cadbury Report (1992: 2.5) define corporate governance as 'the system by which companies are directed and controlled'. While the definition of the Cadbury Report provide guidance on the form of formal governance, it pays limited attention to methods that are not codified or enforced through formal laws (Chrisman et al. 2018). In the governance literature, informal processes have been studied through constructs such as trust and altruism (Cater and Schwab 2008; Karra et al. 2006; Steier 2001) and social networks (e.g., Mustakallio et al. 2002), including behaviours and constructs that facilitate informal dyadic or group interaction between the CEO and the board members (McNulty and Pettigrew 1999; Pettigrew and McNulty 1995). They have been proposed to be even more effective than the formal process in reaching similar ends (Astrachan 2010; Mustakallio et al. 2002), and to have the potential to either reinforce or counteract the formal governance process (Chrisman et al. 2018). Several scholars have also approached processes from the perspective of organisational and individual-level rules (March 1994, Mace 1971; March and Olsen 1989; Sievinen et al. 2020a; Ocasio 1993; Zhou 1993). While formal rules of governance include practices such as setting up board committees, informal rules can regulate how board members conduct political games inside and outside of the boardroom (Pettigrew and McNulty 1995). They can also limit how the board members interact with the CEO and each other (Gabrielsson and Huse 2002; Mace 1971).

Family firm governance can differ from the governance of non-family firms in many respects. Firm governance can be coupled with family governance that seeks to secure cohesion and a shared vision within the family (Mustakallio et al. 2002; Siebels and zu Knyphausen-Aufsess 2012). Typical family firm characteristics also influence governance, including a trans-generational mindset, family members playing multiple roles as managers and owners, and non-financial matters detracting the focus from economic goals (Mustakallio et al. 2002). As a result, informal mechanisms may play a different or a more important role in family firm governance than in other companies (Astrachan 2010; Cater and Schwab 2008; Sievinen et al. 2020a).

\subsection{Dyadic interaction as a form of informal governance}

A dyad is 'the fundamental unit of interpersonal interaction and interpersonal relations' (Kenny et al. 2006, p. 1). However, dyadic interaction does not take place in a vacuum: it is embedded in larger constellation of dyadic relations (Sparrowe and Liden, 1997) and social networks (Liden et al. 2016). We recognise studies focused 
on social networks as a form of informal governance as a distinctive research stream. While many of these studies also discuss concepts of trust, altruism, power and other family firm characteristics, their focus is on how the social context and the processes related to social interaction facilitate or moderate informal governance. Mustakallio et al. (2002) suggested that social control embedded in relationships plays a key role in family firm governance. Family institutions such as informal get-togethers and family councils facilitate social interaction, which—as Mustakallio et al. (2002) proposed-enables having a shared vision among the key stakeholders. Their study suggests that the strength of the shared vision among the family firm owners is positively associated with social interaction, and a shared vision is positively associated with strategic decisions' quality and with commitment. On the other hand, family members may also prefer informal discussions over formal board meetings; thus, a family firm may miss the benefits of a functional board (Bettinelli 2011; Gersick et al. 1997).

Following the findings about board members' influence outside the boardroom (Bezemer et al. 2018; Gabrielsson and Huse 2002; Huse 1998, 2005, 2007; Huse and Zattoni 2008; McNulty and Pettigrew 1999; McNulty et al. 2011; Pettigrew and McNulty 1995), studies on dyadic interaction between the board members and TMT form a sub-stream of research on informal governance based on social networks. In a family firm context, we have only identified a few studies that focus on this area at the micro level. Sievinen et al. (2020b) discussed the role of the owners in a family firm attempting a strategic renewal. They suggested that owners can exercise influence on the CEO and the chair outside the boardroom in order to ensure that strategic renewal is triggered and that the new strategic vision is aligned with the family vision. Sievinen et al. (2019) in turn proposed that non-family board members, including a non-family chair, can influence strategic decision-making through their advisory role, which is enacted through dyadic interactions with TMT members.

Outside the domain of the family firm, we recognise several studies that focus on the role of dyadic interaction in firm governance. Stevenson and Radin (2009) have studied the influence of directors' relations outside the boardroom on board performance, and Westphal and Zajac (2013) have introduced what they call a socially informed view as an alternative to what they deem to be under-socialised governance theories. Many of these studies were conducted in the context of the dual role of CEO/chair (e.g., Westphal and Graebner 2010; Westphal and Stern 2006; Westphal and Zajac 1995, 1998).

We also recognise studies that have focused on the CEO-board relationship in an environment where the $\mathrm{CEO} /$ chair role is separated. While these studies have provided insights into the board's role vis-a-vis management (see e.g., Bankewitz 2016, 2018; Brunninge et al. 2007; Huse and Zattoni 2008), their focus has been on the influence of dyadic interaction on board efficiency. The studies have largely focused on chair-CEO interactions, where power and trust play important roles. Pettigrew and McNulty (1995), Roberts (2002), Roberts and Stiles (1999), Roberts et al. (2005) and McNulty et al. (2011) all recognised that the relationship between the chair and the CEO is important for board dynamics and that the chair nomenclature and origin both influence the power potential of the chair (McNulty et al. 2011). Pettigrew and McNulty (1995) discussed the factors that shape how the potential power 
of a chair is converted into actual influence. Recent examples of research on dyadic interaction include studies by Koskinen and Lämsä $(2016,2017)$ that focused on the CEO-chair relationship and suggested that emergent, non-scheduled practices play a key role in building dyadic trust.

\subsection{Corporate governance related meetings}

Our study also delineates studies on meetings related to corporate governance. While these studies were conducted in the context of stock-exchange listed companies and focused on the interaction of executives and external parties (such as financial analysts, investors or auditors), they offer relevant insights for our field of study. They address both private and public meetings (Abraham and Bamber 2017), with the first stream including one-on-one investor-investee meetings, for example, and the latter featuring AGMs and analyst events related to the release of corporate earnings. A line of this literature has applied the key concepts of Erving Goffman $(1959,1961,1974)$ including 'special self' as 'a specific actor performing a specific performance at a particular encounter' (Johed and Catasús 2018, p. 370) as well as impression management and concealment of attributes that are not part of the actors' idealised self.

For our line of research, studies on meetings in private settings that feature dyadic interactions are the most relevant ones. For example, Solomon and Darby (2005) and Solomon et al. (2013) have studied one-on-one meetings on ESG (environmental, social and governance) matters between the institutional investors' representatives and the operational managers of the investees. Solomon et al. (2013) show that this dyadic interaction follows unwritten rules whereby ESG issues are subordinated to financial matters. The meetings can be characterised more as relationship building than as triggers that actually alter investors' investment behaviour. Unlike Imam and Spence (2016), who show that sell-side analysts consider management to intentionally hide or delay information on poor performance, Solomon et al. (2013) suggest that buy-side analysts operate within a framework of the managers not managing the impressions to deceive investors intentionally. While having different theoretical approaches, both Solomon et al. (2013) and Solomon and Darby (2005) argue that one-on-one dialogue between these powerful parties can lead to the creation of a joint myth about the state of the affairs.

Another topic of study is the role of financial analysts in events related to public corporate governance, such as Q\&A sessions in the context of earnings releases. Graaf's (2018) findings depict earnings announcements as a stage wherein analysts must ask certain questions and avoid others. Abraham and Bamber (2017) in turn conceptualise the company Q\&A with the analysts as a stage for impression management where the analysts' self-promotion plays an important role. Johed and Catasús' (2018) study highlights the importance of the auditors' back-stage preparations with management prior to the AGM. The results suggest that these activities are considered by the auditors as necessary to avoid disruption in the AGM. The role of the private rehearsal at the back-stage prior to the interaction at the front-stage has also been highlighted by Solomon et al. (2013) and Roberts et al. (2006); however, 
the multiple interpretations of the back-stage/front-stage dichotomy reflects its relative and contextual nature. Solomon et al. (2013) consider investor/investee views and behaviours in private meetings as front-stage and investors' actual investment decisions and investee's actual (rather than presented) actions outside of the meetings as back-stage. Johed and Catasús (2018) in turn refer to management-auditor meetings and related agreements prior to the AGM as back-stage activity and AGM as front-stage-perspective that align with those of Graaf (2018) who observes that 'team performances typically require preparation and coordination in the "backstage" region, allowing the "frontstage" performance to run without disturbance" (p. 1235). This conceptualisation of back-stage activity as 'meetings on meetings' is highly relevant for our research focus.

We conclude that research on informal governance and CEO-board relations in family firms have provided a more nuanced view on the corporate governance than that offered by normative governance theories alone. Also, formal corporate governance is increasingly recognised as being only the tip of the iceberg in relation to the full extent of corporate governance, including dyadic interaction in meetings related to corporate governance. However, the intersection of family firm governance, informal processes and dyadic interaction remains scarcely researched.

\section{Methodology}

\subsection{Research approach}

A qualitative research approach, which engages in context-specific inquiry and does not treat the governance processes as taking place in a 'black box' or as 'standard' offers (Ahrens and Khalifa 2013) provides an important alternative for quantitative methods. We chose to focus on two companies to ensure an in-depth approach that would help us reveal the micro-level behaviours of the key organisational actors. Our research design selection of two cases was not done to increase the generalisability of the study or to do a comparative study. Our goal was to enrich the data and ensure a variety of perspectives by selecting two companies that share the key contextual elements: they are both later generation family firms where the main owners participate though serving on the board and both firms are attempting a strategic renewal.

As the board can play a key role in strategic decision-making and the rejuvenation of firm strategies (Gopinath et al. 1994; Hass and Pryor 2005), the context of strategic renewal suggests active board involvement. Gaining access constitutes a major obstacle in governance studies (Leblanc and Schwartz 2007). Hence, while the companies were chosen through a purposive method, as both are later-generation family firms undergoing strategic renewal processes, the access that the owners were willing to grant us played a key role in the selection of the firms. Also, as one of the writers of this article holds a board seat as a non-family member in one of the case companies, there was immediate trust that supported the data collection in this company. To ensure the impartial perspective necessary for informed theorising, all 
of the data collected, along with its analysis and the interpretations suggested by this writer were carefully reviewed by the two other writers.

From the epistemological perspective, we adopt a largely interpretivist view. However, we make two concessions to this. First, while we considered the informants as knowledgeable agents who can describe their own experiences, motivations and emotions, we used data and source triangulation to certain extent to have a better understanding of some of the past events in the companies we studied. Second, we assume that our findings based on a limited number of case studies, are not fully idiosyncratic. While our study has important limitations related to the research method and contextual factors discussed in 3.5 Limitations, we believe that one can generalise from a case study if it generates principles with obvious benefits to another domain (Gioia et al. 2013).

\subsection{Data collection}

We started the data collection in 2017 with the interviews in Case Company 1. Apart from the CEO, the chair and the owners, we also interviewed other governance actors, namely non-family board members (other than the chair). This process helped us to understand the larger context of the case companies' governance. We were given access to the company archives, which included board materials such as agendas, presentation materials and minutes. In addition, we collected publicly available data-such as company marketing materials, white papers, media coverage and industry reports - to gain an insight into the firm's background and its industry.

We continued the interviews in 2018 and 2019. To study the board members' interaction outside the boardroom in depth, we conducted more interviews with Case Company 1, as well as adding interviews with Case Company 2 to our data set. Similarly to Case Company 1, with Case Company 2 we also had access to the company archives and we utilised the publicly available information and company marketing materials as secondary data. We felt that the fact that we collected the data through several interviews over an extended period of time and interviewed many of the key actors several times helped us to create a trustful relationship with the interviewees.

All interviews took a semi-structured form and were scheduled to last from 60 to $90 \mathrm{~min}$ (see Table 1: 'List of interviews'). As we gained more understanding, we allowed the prior interviews to influence the subsequent ones, and some interviews had a more in-depth focus on selected topics. We designed our questions to focus on the behaviours and actions of the informants, but we also added questions to address their normative beliefs on interaction outside the boardroom.

\subsection{Data analysis and theory articulation}

To ensure the transparency and academic rigour of our approach, we chose to apply the Gioia method (Gioia et al. 2013; Nag and Gioia 2012), which provides a systematic approach to concept development. We used the primary and secondary data to build a plausible view of the events for each company. We then used a combination 
Table 1 Interviews

\begin{tabular}{ll}
\hline Date & Interview \\
\hline 2.6 .2017 & An owner, member of the board case 1 (1) \\
29.6 .2017 & An owner, member of the board, case 1 (1) \\
18.7 .2017 & A non-family board member, case 1 (2) \\
24.8 .2017 & An owner, member of the board, case 1 (3) \\
31.8 .2017 & A non-family board member, case 1 (4) \\
4.9 .2017 & A non-family board member, chair of the board, case 1(5) \\
20.9 .2017 & An ex-CEO, case 1 (6) \\
13.10 .2017 & A non-family board member, case 1 (7) \\
16.10 .2017 & CEO, case 1 (8) \\
27.8 .2018 & A non-family board member, chair of the board, case 2 (9) \\
28.8 .2018 & An owner, member of the board, case 2 (10) \\
29.8 .2018 & An owner, member of the board, case 2 (11) \\
1.10 .2018 & A non-family board member, chair of the board, case 1 (5) \\
19.10 .2018 & CEO, case 2 (12) \\
22.10 .2018 & Owner, member of the board, case 1 (1) \\
26.10 .2018 & CEO, case 1 (8) \\
18.9 .2019 & An owner, member of the board, case 2 (11) \\
23.10 .2019 & A non-family board member, case 2 (13) \\
\hline
\end{tabular}

of NVivo software and manual analysis to identify data-driven categories. These were based on our initial coding of individual interviews (which were named after a representative quote, to retain the voice of the informants from each company separately, along with common themes across the cases). This process created our firstlevel data structure.

At the next stage, our process revealed themes that related to the distinctive roles and behaviours of the owners, the CEOs and the chairs. With the help of the relevant literature, the emerging concepts relating to the roles, behaviours and the content of the interaction were grouped to form second-level themes. Assembling the secondlevel themes into aggregate dimensions and into a full data structure enabled us to reveal the relationships between the organisational actors, the content of the interaction and the rules regulating the interaction. As we worked in an iterative way, we gradually reached a stage where we felt that additional interviews and follow-up questions no longer provided additional information, or that its scope was beyond our research focus.

We used several approaches for getting feedback on our interpretations. The diverse backgrounds of the writers of this article, both in research and practice, stimulated alternative views. We also received member checking from the informants. As our interpretations of the data started to take form, we also had one-on-one and group discussions with seasoned executives and other practitioners to test our ideas. 


\subsection{Case descriptions}

\subsubsection{Case 1}

3.4.1.1 Company history and renewal strategies Established in 1921, the key products of Company 1 - lighting controls and luminaire components_-generated sales of EUR 76 million in in 2017, of which over 97\% came from European countries outside Finland and from Asia. The key sites are in Finland and the UK, supported by the global sales organisation.

While the first ten years of the twenty-first century were characterised by a successful turnaround of the component business, by 2014 the owners of Company 1 had started to grow concerned about the long-term sustainability of the firm. The company balance sheet remained strong, but sales had been declining for several years. Driven by the introduction of a new light source, LEDs (light-emitting diodes), the industry was undergoing radical changes, which impacted both the component and the control businesses of the firm. From 2014 onwards, the renewal strategies included the appointment of new non-family board members including a new chair, the appointment of two new, non-family CEOs, reducing costs and reallocating resources so that lighting controls were recognised as a key strategic growth business.

3.4.1.2 Company governance The same family has controlled the company since its foundation, and in its fourth generation, the shares are held by six cousins. At the time of the data collection, no family members were involved in its daily management, but one of the owners headed the company in the 1990s. During the period of our focus, 2014-2018, the board was composed of six members: two of the owning family members and four independent, non-family board members, one of whom served as a chair. The non-family board members represent diverse backgrounds and functional expertise in the global technology business. Table 2 at the end of this section lists the characteristics of the formal firm and family governance processes of both case companies.

\subsubsection{Case 2}

3.4.2.1 Company history and renewal strategies Founded in 1906 as a sawmill in the southern part of Finland, the company focuses on plywood, sawn timber, chipboard and other wood products. In 2017, it generated sales of EUR 270 million, and over $80 \%$ of its products were exported to other countries in Europe, to Asia and to the Middle East. The company operates production facilities in Finland, Russia and Poland.

By the middle of the first decade of the twenty-first century, the firm had successfully internationalised and diversified. However, the financial crisis triggered in 2008 had a severe effect on the indebted company. The equity ratio was low for a cyclical environment, and covenants restricted investments. Starting in 2014, the renewal strategies included the appointment of new, non-family board membersincluding a new chair and a new, non-family member $\mathrm{CEO}$-along with reducing 


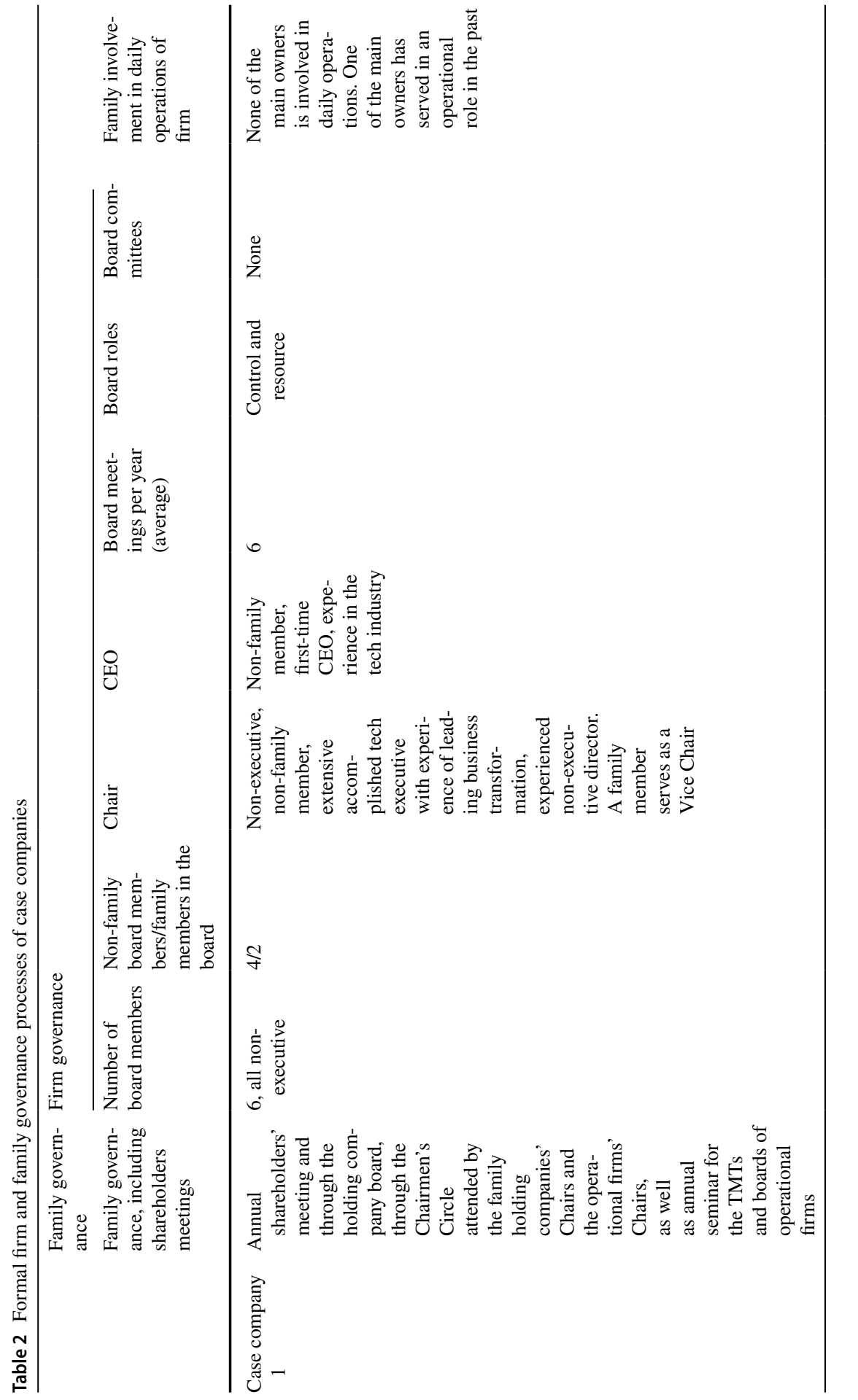




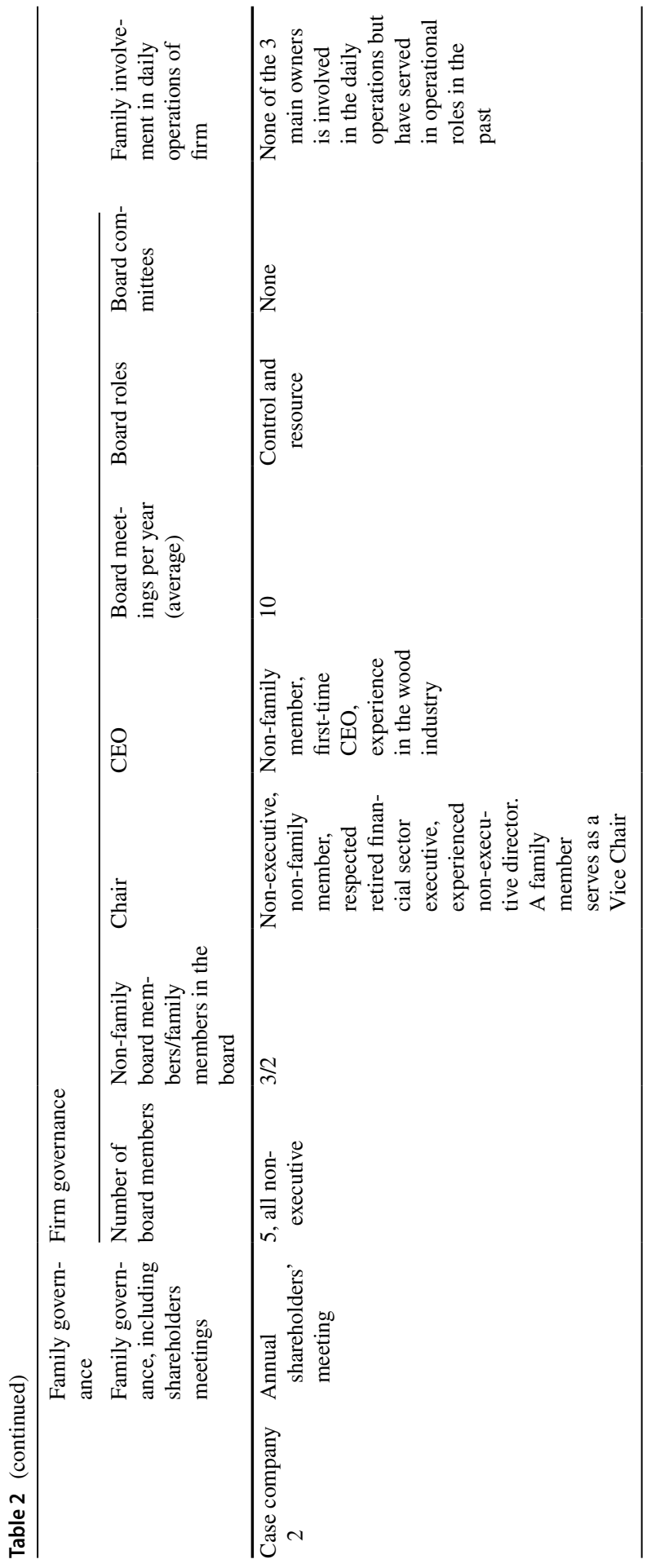


costs, the renegotiation of loans, the disposal of selected assets and investments into new growth opportunities.

3.4.2.2 Company governance The parent company of the group is $100 \%$ owned by the founders' three grandchildren and their children, while the minority of one of the subsidiaries is held by a more diverse group of the same (extended) family members. The board of the parent company consists of two representatives of the third-generation main owners, as well as three independent non-family board members with experience in the forest industry, the financial sector and international business. The owners serving in the board have in the past served as executives in the company. At the time of the data collection, one of the third-generation main owners' children served in an operational role in the firm.

\subsection{Limitations}

Our case study approach, with its limited number of cases and certain contextual factors, creates important limitations. While it enables studying the phenomenon of interest in detail, other methodologies would be needed to enable replication logic.

The Finnish governance system is based on civil law. The board is responsible for the overall management of the firm, as well as for oversight of internal controls and risk management, while the CEO performs the daily administration. In larger, professionally managed companies, the CEO and chair roles are typically separated and board members are not typically part of the management team. As observed by Sinani et al. (2008), the informal governance systems in Scandinavian countries (Denmark, Norway and Sweden) are characterised by trust, information diffusion and reputation mechanisms. We argue that Finland shares these characteristics. Both case companies also share important company-level contextual factors. The chairs and the CEOs are relatively newly appointed, which may affect their relations with each other and the owners. In addition, the main owners participate through governance in both companies, and the professionalisation of the firms has been well on its way for several years. Our findings may not be relevant in significantly different governance and company contexts. However, we believe that while our findings may not be applicable to all family firms, they can be relevant for later-generation family firms where family involvement is through board membership, the board is active and it includes non-family members.

\section{Analysis and discussion}

\subsection{The dyadic back-stage interaction of the CEO and the chair of the board}

In Case Company 1, the current CEO is experienced in the technology business, but the position is his first as a CEO. The chair feels that this makes the CEO more open to the chair's support as a sounding board than a more seasoned executive would be. The current CEO is indeed vocal in his appreciation of the access to the board 
members' expertise outside of the boardroom. On the other hand, the data suggest that while the former CEO had also been in his first CEO position, he emphasised the risks that relate to a CEO 'asking for advice from the board' and considered informal back-stage interaction primarily as an opportunity to gain early support for a proposal prior to board meetings.

While unexpected events can necessitate continuous ad hoc communications, the interaction of the CEO and the chair in Case Company 1 is structured around prescheduled weekly discussions:

We have scheduled to discuss for an hour or an hour and a half every Friday, longer if we meet face-to-face and shorter if we talk over the phone. But at minimum, we talk every week, and then, if you include communications such as WhatsApp and text messages, [...] I think it is two or three times per week. (Chair of the Board, Case Company 1).

The content of these discussions is largely driven by the CEO, who maintains a list during the week on the topics he wants to take up in his weekly discussions with the chair. In these discussions, he reports on the execution of items compared against the targets decided on by the board, as well as his planned next steps. This information supplements the data available in the board meetings and board materials. The chair readily offers his support as a sounding board. At the same time, he receives timely information from the CEO on the firm's performance, which supports him in monitoring it. However, he emphasises the importance of not deviating from what he considers to be orderly corporate governance:

We do not make any big decisions. [We talk about] operational matters, have sounding board-type discussions; and then, on the other hand, I get to know how things are progressing [...]. (Chair of the Board, Case Company 1).

The chair also recognises his role in giving confidence to the CEO when making decisions that do not require board approval and executing actions that relate to the renewal process. The CEO, while emphasising that a CEO should not seek advice in the sense that he or she fears making decisions on his or her own, considers this type of support to be important:

An example from this week is that we had to let someone go. Before this was done on Tuesday, on Monday the CEO told me how he was going to do it. It was more of a sparring discussion as the decision had already been made. (Chair of the Board, Case Company 1).

From the CEO's perspective, part of the interaction with the chair is also the feedback received following board meetings:

I think it is important that the board can give the CEO feedback, and the Chair of the Board is the best positioned to provide it. [...] When you are in a board meeting, you are fully immersed in it. (CEO, Case Company 1).

The CEO of Case Company 2 is also in his first CEO role. While preparing the agenda for the next board meeting is the primary purpose of the chair and the CEO's 
bi-weekly discussions, they also go through the items that supplement the information provided to all board members. These include longer-term issues and the firm's performance related to the renewal process. According to the chair of Case Company 2, the key purpose of this interaction is for them to 'find the same wavelength' in regard to whether the topic is ready to be brought to the board for discussion and/ or for making a decision. These back-stage discussions provide the CEO with information on how to position the matters to be decided and the questions to expect. On the other hand, similarly to Case Company 1, the chair of Case Company 2 also avoids trying to steer the firm matters that belong to the board's agenda forcefully in his dyadic interaction with the CEO.

Renegotiating financing and carrying out selected asset disposals has played a major role in Case Company 2's renewal strategies. Hence, the CEO valued the chair's financial industry experience and contacts:

During the time we renegotiated the financing of the company [we had more frequent communications], and that was because of my background. As the CEO had a similar background, we had lots in common; and then the other thing was that I was more active towards the financiers, together with the CEO, and sometimes I even helped him with the contacts I have. (Chair of the Board, Case Company 2).

Both firms have appointed experienced chairs whose key experience and contacts reflect the key uncertainty of each firm: the rapidly changing technologies in Case Company 1 and the dependence on external financiers in Case Company 2. The interaction between the CEO and the chair in our case companies ensures that the chair remains in touch with the progress of the renewal's execution and with business performance in general.

The CEOs interviewed also appreciate the chance to have a sounding board in discussions on matters that are more operational in nature and do not require a board resolution. They consider that one-to-one interaction ensures that the CEO can receive more support than in the board meetings, as he or she can focus on the areas that are within the chair's areas of expertise. These findings reflect the extant governance literature suggesting that boardroom challenges-such as digressions and cognitive switching between short- and long-term issues (Garg and Eisenhardt 2017) or status competition, which are inherent in any group (Bendersky and Hays 2012) — can be avoided in interactions outside the boardroom. Apart from her or his experience and access to external resources, the chairs in the case companies also control information on the board's view of the CEO's performance. The case company CEOs appreciate this information, which they consider helpful in improving their performance and in developing themselves as professionals.

Both the CEOs and the chairs of the case companies are conscious of the risks of interactions outside of the boardroom jeopardising what the informants consider 'good governance'; for example, making decisions that should be on the board agenda. From a processual perspective, we relate this to their being motivated to adopt organisational characteristics that enhance the legitimacy of governance, as evidenced by Westphal and Graebner (2010) and Westphal and Zajac (1998). The finding can also be interpreted as a part of the 'role play' of the governance actors, 
i.e., emphasising the importance of ensuring that back stage behaviour is in line with the expectations of the front-stage social role (cf. Solomon et al. 2013), as a CEO or board member should not violate the rules of 'good governance'. However, as McNulty and Pettigrew (1999) proposed, the board members who engage in the interaction outside of the formal process can shape strategic choice, change and control effectively as individuals, outside the authority of the board as a coalition. In our case companies the CEOs use their dyadic discussions prior to the meeting to explain their proposal rationale in greater detail—not being bound by the time limitations of a board meeting. Hence, in our case companies the chair's insight and support are gained prior to the actual board meeting, while the chair can influence the CEO's proposals through advice and/or guidance.

The data also provides evidence that CEO-Chair dyadic relation can provide a ventilation possibility for the CEO after the board meeting. A board meeting can sometimes be a high-stress situation for the CEO. At times, the CEO can consider a board member's remark to be off-the-mark or inconsiderate. However, because of the power imbalance between the CEO and the board members, the CEO may not necessarily be able to openly express his or her feelings at that time. The data shows that a CEO can discuss his or her frustrations one-on-one with the chair, and in doing so, feel that the matter is 'done and dusted, [and one can] move on.' In such interactions, we understand the chair to temporarily assume a role of a trusted partner instead of representing the authority that the board as a coalition inherently holds over the CEO. If family members disagree about important company-related matters, the data shows that the CEO and the chair may also privately discuss the way forward. In such interactions, the CEO and the chair's positions as non-family members discussing without family members can play a key role finding an appropriate solution.

\subsection{The dyadic back-stage interaction of the CEO and the owners}

In Case Company 1, the initial purpose of the monthly interaction between the current CEO and one of the owners was to ensure that the change in leadership would not disrupt the renewal process that had been initiated. The interaction was felt to emphasise the owners' commitment to realising the change and making it visible to the new CEO. However, half a year after the new CEO had joined the firm, the owner requested less frequent meetings to avoid the dyadic interaction clashing with board meetings and to ensure that the matters discussed would not become too operational:

Once the new CEO has joined, it is important that the chair is given space to work with him or her. [...] Otherwise, when you have a non-family member as the chair, the CEO can start to think that they report to the owners, not to the chair. (Owner, Case Company 1).

After the induction period, the purpose of the dyadic meetings (which now take place every six or eight weeks) is for the CEO and the owner to discuss the longterm direction of the company. In these meetings, the owner shares his knowledge 
of the firm and its heritage based on his long tenure with the firm both as an owner and as an ex-executive, and in return he receives the latest information on the firm's progress. Similarly to a chair recognising the risk that decisions may be made outside the boardroom when they interact one on one with the CEO, the owner is also sensitive about this matter when discussing issues with the CEO outside of the boardroom:

[The new CEO] has never asked [in these meetings] for my approval for something, and that is not the purpose of [my session with him]. Instead, these meetings are more to ensure that I can transfer to him what I would call tacit knowledge. (Owner, Case Company 1).

The data show that the CEO of Case Company 1 values the owners' insight into people-related matters, as the owners know many of the firm's employees well. In addition, the CEO also appreciates the opportunity to gain information on the owners' opinions and family goals, although he feels that, formally, the owners' expectations should be communicated in board meetings, which aligns with the findings of Gabrielsson and Huse (2002):

At the end of the day, it is the owners who own the firm and use the owners' voice, and hence it is much in my interest to have access [to the owners]. (CEO, Case Company 1).

One of the owners in Case Company 1 feels that his interaction with the CEO outside of the formal governance process at the back-stage influences the board meetings indirectly. He compares this role to a sovereign's duty to be consulted, to encourage and to warn, as defined by Walter Bagehot (1867), rather than the owners dictating the operational agenda or making decisions outside of the boardroom, at the back-stage. As the owner provides input anchored to his long-term vision to the CEO in one-on-one sessions, he believes that this gives the CEO the confidence to bring his proposals to the board meetings.

In Case Company 2, the interaction outside of the board meeting between the CEO and the owners who serve on the board is not pre-scheduled. It is driven on the basis of need, such as when the CEO seeks their advice or when the owners feel that they require further information on the firm's performance-that is, information supplemental to what is available to all board members.

Also in Case Company 2, the owners who in the past have served in managerial roles in the company can provide the knowledge of long-term employees for a new CEO who is not a family member. In return, the owners appreciate the information that the CEO can provide on the firm's short-term performance:

I have an office [at the headquarters], so I go there even though I do not have an operational role [...], just some projects. So, I visit the [headquarters] a few times every week, and when I go there, I always talk with the CEO, who has his office on the same floor. (Owner, Case Company 2).

However, one of the owners recognises his wish to share more of the firm's history with the non-family member CEO: 
In our firm's history, there have been different times, good and bad [...], and I think one needs to know and acknowledge this history. [These are the stories] I would like to tell [the CEO]. (Owner, Case Company 2).

While appreciating the interaction with the CEO outside of the boardroom, the owner is sensitive about ensuring that the chair is included in the communications:

I do not want to bypass the Chair of the Board [...]. If I am in touch with the CEO, I ensure that the chair knows about it. (Owner, Case Company 2).

However, the data also suggest that this principle is not always followed consistently if an owner feels strongly about a topic that the owners consider belongs to the 'owners' domain' - most importantly, the treatment of long-term employees when a firm needs to make lay-offs. In these cases, the owners of case companies can guide the CEO directly in regard to the desired principles.

Unlike the non-family CEO and the chair, who typically are considered to enact only professional roles within the organisation, family firm owners are often perceived as having many roles in a family business context. These include being a family member and owner, as well as a board member and an (ex-)executive (Sievinen et al. 2020a). Our data indicates that an owner may engage in lively internal dialogue as he or she assesses the role and its appropriateness in a family business context. Our data show the owners' sensitivity to multiple roles when interacting with the CEO:

I have become very sensitive about it [in the dialogue outside the board meetings] [...] so nowadays I always say [to the CEO] that 'Now, I say this as a family member', 'I say this as an owner' and 'I say this as a member of the board of directors'. (Owner, Case Company 2).

The data indicates that owners can postpone expressing their views in the boardroom until later to ensure that non-family board members feel that they can express their views freely. Interaction with the CEO outside the boardroom can offer them an opportunity to share their intimate knowledge of the firm and the owners' expectations in an informal way and ensure that there are no misconceptions.

\subsection{The dyadic back-stage interaction between the chair of the board and the owners}

In Case Company 1, the chair and one of the owners have a discussion every few weeks and meet face-to-face every month. However, events such as hiring or firing a CEO can increase this frequency. While the chair can call the owners to meetings between these to inform them of an important issue that has emerged, ad hoc contact is rare. One of the owners acts as a key contact with the chair.

Discussions with this owner are focused on strategy and personnel changes, the progress of the renewal towards the agreed vision, market changes and questions that relate to the structure and location of the operations. Both from the chair's and the owner's perspective, the primary purpose of these discussions is to provide additional transparency for the company: 
the purpose is $[\ldots]$ that the owners know what's going on, and that there are no big surprises coming up, in the board meetings or otherwise. (Chair of the Board, Case Company 1).

we ensure that $[\ldots]$ we [the owners] know the status of the business prior to the board meetings. (Owner, Case Company 1).

Similarly to Case Company 1 , one of the owners on the board in Case Company 2 has assumed a spokesperson role towards the chair. When the chair seeks the owners' guidance, he typically starts with this spokesperson and only after that extends the discussion to the other owners. The chair varies the frequency of his communications with each of the owners in line with their expertise and personality. For one of the owners, the chair has become a trusted person in regard to people and family ownership-related matters in general. The chair talks more about renewal-related business matters with the other owner, who is familiar with the plywood business.

In both companies the chair - thanks to his frequent contact with the CEO-can pass on the owners' information about the firm's performance, while the owners share their expectations and goals for the firms with the chair. The owners feel they can benefit from the back-stage discussions with the chair outside of the time constraints of board meetings. They consider that these discussions provide the owners with an opportunity to provide the chair with detailed information on the family's expectations and goals, as well as to share their thoughts on the new strategic directions. None of the informants considered the dyadic interaction as a key forum for communicating the owners' requirements. However, the data suggest that the appointment of a new CEO in our case companies forms an important case wherein the discussions between the chair and the owners at the back-stage are important, even though it remains the task of a chair to facilitate a board decision regarding a new CEO so that both owners and non-family board members are aligned.

The data also suggests that dyadic interaction between the chair and the owners can serve as a forum for the owners to reveal personal and nuclear-family related matters - such as family relations or the involvement of next generation into the business - that may influence their views on family firm related decisions. We understand that these topics may be excluded from discussion in the board meeting for two reasons. First, in the board meetings the owners (like any other board members) must attend to the interests of the company and all shareholders. Therefore, owners may restrict their disclosure of personal interests when acting as a board member. Second, owners may prefer not to discuss what they consider private matters in formal board meetings attended by a larger group of people.

\section{Concluding discussion}

1. Our results suggest that the CEO, the chair and the owners can spend significant time on dyadic back-stage interaction as a part of firm governance. It can offer the chair and the owners a privileged position from which they can influence decisionmaking before, after and between board meetings. The dyadic interaction can serve many process-oriented purposes. Our data reveal that it is used for preparing for 
the board meetings, complementing and clarifying board decisions as well as for communicating and creating organisational commitment to family expectations and goals.

\subsection{Preparing for board meetings}

Preparing for board meetings can take a significant amount of time in CEO-chair dyadic interaction (see Table 3 below). This interaction can affect board meetings in terms of their agendas and presentations. While the data do not suggest that the chairs 'censor' the CEO's board presentations, the chairs can have an indirect influence through discussions that aim to get the chair onto the same 'wavelength' as the CEO when preparing for a board meeting. Our data show that owners also have an influence on the board's agenda and the CEO's proposals. The data suggest that the owners can offer the chair views on the items they wish to see on the board agenda. Also, while the owners' dyadic interaction with the CEO can be less intense than with the chair (see Table 3 for intensity of the governance actors involvement), the data show that the owners can assume a Bagehotian role to give the CEO confidence prior to her or his board presentations. This finding supports the evidence of McNulty and Pettigrew (1999) on the individual board members' roles in 'advising caution' or 'offering encouragement' to the CEO prior to proposals being brought to a board meeting.

The cases reveal that owners' dyadic interaction with the CEO and the chair can also serve the particular circumstances of family firms, including communicating and creating organisational commitment to family expectations and goals. Kotlar and De Massis (2013) suggested that family goals become more prominent when the family members extend their influence within the organisation through social interactions. While this dynamic can be viewed as providing a control tool for the owners (as it can curb the CEO's power), in our case companies this behaviour showed also potential to create information asymmetry between the other board members and the CEO.

Our findings on the CEO-chair-owner interaction prior the board meetings could also be interpreted as 'directive dominance' enacted by the chair and the owners at the back-stage to structure the front- stage performance by guiding how the roles at the board meeting are enacted (Goffman 1959; Graaf 2018). Hence, we suggest that back-stage discussions could influence not only the content but also the conduct of front-stage discussions.

\subsection{Clarifying board resolutions}

While the board as a coalition can control the interpretation of its decisions through monitoring their execution, as well as through written minutes of the meeting, our data suggest that the chair and the owners can also have an influence outside of the boardroom on the way the board's decisions are put into practice. After the board meeting, the data show that the chair can help the CEO to clarify how the board's decisions should be interpreted and executed. In our case companies, the owners 


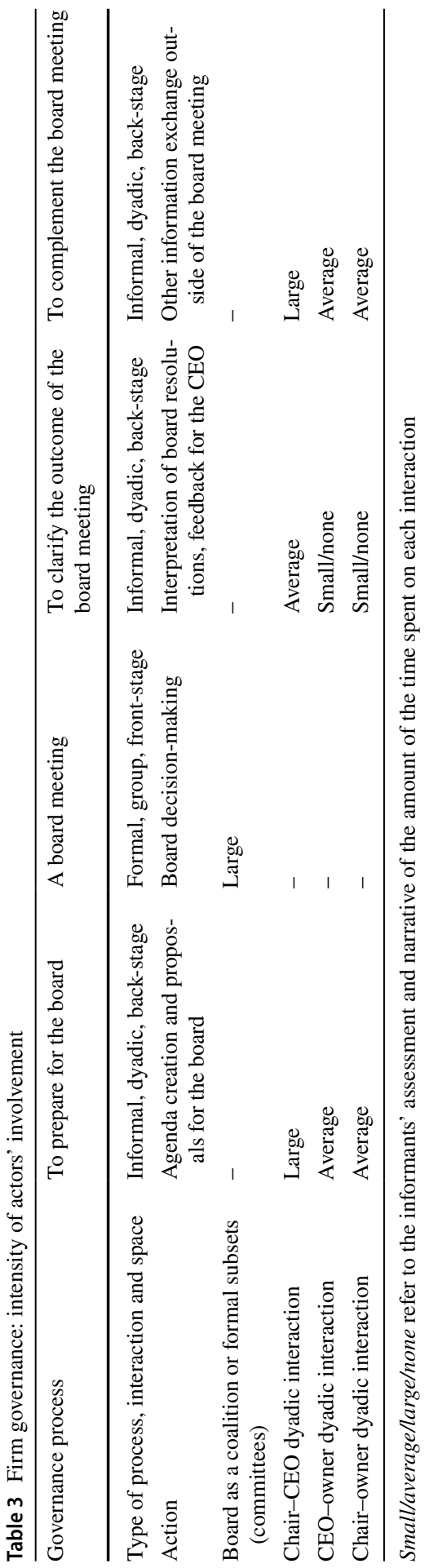


shy away from attempting to influence operational matters through the CEO after the formal decision-making. However, in matters that the owners consider highly important (in our data, how the employees are treated in a redundancy situation or concerning renewal options), the data show that the owners engage in dyadic interaction with the CEO before or after the board decision. The data suggest that this back-stage behaviour can also relate to the owners' desire to ensure organisational adherence to family expectations and goals.

\subsection{Complementing board meetings}

The tasks of preparing for board meetings and clarifying board resolutions are tied to the schedule of formal governance processes. However, our data reveal that the dyadic back-stage interaction can also be supplementary to the board meetings and take place independently from the board schedule. In our case companies, it includes discussions between the CEO, the chair and the owners on matters that are not considered as belonging to the board agenda, but in which the chair and the owners have relevant experience. In our cases, both chairs are experienced and are therefore able to act as sounding boards for the CEO. The owners, thanks to their long tenure with the firm, can share their experiences on the family firm's ways of working and expectations in that regard. This behaviour emerges strongly in our data, and it may be attributable to both the case companies' CEOs and chairs having started their tenures relatively recently. Hence, the finding can suggest the importance of dyadic interaction between key governance actors as a channel for owners to contribute to the success of a new CEO through their knowledge of the family firm.

Our data suggest that decision-making can be viewed as a multi-step process wherein informal and formal processes intertwine and board members are involved to varying degrees, both in back-stage and front-stage interactions. The formal board meeting is a front-stage arena where the board has the legal authority to make decisions and where the directors carry out their legal duties (Bezemer et al. 2018). However, actual decision-making is the final stage of a long process (Johed and Catasús 2018; Pettigrew 1990; McNulty and Pettigrew 1999). McNulty and Pettigrew (1999) suggested that board members can influence a firm's strategy by shaping its content, as well as the processes used to formulate it, through informal dialogue outside of the boardroom. Similarly, owners who serve on the board (Sievinen et al. 2020b), as well as non-family board members (Sievinen et al. 2019), have been shown to exert influence on family firm decision-making outside the boardroom. We build on these findings by contributing a process component which suggests that the board decision-making can be viewed as a multi-step process where informal and formal processes intertwine and board members can be involved to varying degrees. This intertwining of formal and informal can also be viewed as a sequence of backstage and front-stage activities where dyadic back-stage interaction plays a key role in ensuring that front-stage board meetings' can run without disturbance (cf. Graaf 2018).

Our data suggests that informal dyadic interaction can be based on the combined structural, prestige and expert power of the chair and the ownership and expert 
power of the owners (Finkelstein 1992; McNulty et al. 2011). This dynamics can offer the chair and the owners of a family firm a privileged position to directly influence the content of board decisions before, after and between board meetings. In our case studies this enables the chair and the owners to enact their board roles to 'shape the content, context and conduct' and to exert control over the management (McNulty and Pettigrew 1999) in formal and informal settings. Our findings (see Table 3) suggests that dyadic informal processes can complement formal ones (by preparing for and supplementing board meetings) and compensate for them (by clarifying the outcome of the board meeting when it is unclear) (Chrisman et al. 2018; Nordstrom and Jennings 2018; Vardaman et al. 2018).

However, in our case companies informal processes do not act as a substitute for formal ones. Our case companies provide no evidence that back-stage discussions would replace front-stage interaction, as the two serve different roles in the governance of our case companies.

Our findings on the close relationship between the CEO and the chair are in line with the previous research (e.g., Koskinen and Lämsä 2016, 2017; Roberts and Stiles 1999), but they also suggest that in the context of family firms, the importance of CEO-owner and chair-owner relations should not be dismissed. They may be enacted less frequently than that of CEO-chair relations (see Table 3), but the power that the owners have through their equity holding (McNulty et al. 2011; Sievinen et al. 2020b) can magnify the influence of this behaviour.

2. Dyadic interaction can influence the board's decision-making. To avoid negative influence, the actors are shown to self-regulate their back-stage behaviour through informal rules. The board members' behaviour outside the boardroom affects boardroom dynamics (Pettigrew and McNulty 1995). The back-stage dyadic interaction forms a 'fluid space' that Vaivio (2006) describes as 'elusive, almost private spaces of organizational action' (p. 735) that affect involvement and accountability.

Based on the work of Barroso-Castro et al. (2017), we define cognitive conflict as board members expressing different views, preferences and approaches when making a decision as a coalition. Several scholars suggest that cognitive conflict can have a positive influence on board performance (e.g., Barroso-Castro et al. 2017; Finkelstein and Mooney 2003; Forbes and Milliken 1999), while a high degree of social cohesion between the board members can promote groupthink (Westphal and Bednar 2005). In turn, Carpenter and Westphal (2001) observed that network ties channel influence as well as information. The extant research has largely referred to the lack of conflict with dominant CEOs, group size, a lack of diversity in terms of directors' backgrounds and group working techniques (see, e.g., Finkelstein and Mooney 2003; Forbes and Milliken 1999) as sources of reduced cognitive conflict. We suggest a novel source for it. Dyadic interaction at the back-stage can align the views of a subset of the board before the board, as a coalition, is able to discuss and decide on the agenda items. In our cases, this behaviour includes the practice of the CEO and the chair ensuring that they are on the same wavelength prior to the board meetings, as well as the owners' Bagehotian guidance for the CEO prior to the CEO preparing board proposals. Similarly, we recognise that the chair and the owners' can have discussions prior to the actual board decision, which can result in 
the views converging towards those of the owners. The data show that decisions on key strategic directions and the appointment of a new CEO are preceded by the owners and the chairs discussing the viable alternatives at the back-stage hence potentially aligning the views of both the owners and the non-family board members. We suggest that these behaviours, even when not enacted in a pressuring way, can lead to the CEO's proposals for the board and the board's decisions remaining within 'Overton's window' (a concept named after Joseph P. Overton by Joseph Lehman of the Mackinac Center for Public Policy). One can, of course, argue that even without this safeguard, the board would be unlikely to make decisions that were unacceptable for the owners or the chair (the owners can always change the board, and the chair can resign). However, we propose that as this window can frame what the CEO proposes to the board and the acceptable options for the dominant coalition, it can effectively reduce the number of alternatives proposed and differing views expressed in the board meetings.

Our findings indicate that the actors recognise that dyadic interaction can be opaque, with the potential to contradict or bypass formal governance. To avoid this, the actors in our case companies self-regulate their behaviour through informal rules. In line with the findings of Sievinen et al. (2019, 2020a), Westphal and Graebner (2010) and Westphal and Zajac (1998), our data shows that there are several rules - which are similar between the two companies - that are adopted by the governance actors in order to ensure that informal governance is aligned with what is considered 'good governance'. These rules define the conduct of governance roles and the data suggests that the actors found it important to emphasise their own as well as the other actors' commitment to them. For example, in our case companies family firm owners, the non-family chair and the CEO make an effort to ensure that decisions that belong on the board agenda are not made in dyadic discussions, and that the chair is always kept aware of the content of the discussions between the $\mathrm{CEO}$ and the owners. These rules focus on ensuring that decisions that belong to the board agenda are made formally in the board meetings. In our case companies, however, they do not address the potential risks that relate to potential hazards resulting from a reduction of constructive cognitive conflict between the subsets of the board members.

3. Our findings suggest that dyadic relations may serve specific emotional and relational goals that may not necessarily be achieved through a larger group interaction. The chair's role in achieving the potential benefits may be central. Our data suggests that dyadic interaction may sometimes be considered more effective than larger group interaction. For example, in one of the case companies the owners used to be involved in preparing the board agenda together with the CEO and the chair, but then it was decided that the CEO and the chair would do this largely themselves.

However, our results indicate that some dyadic interaction between the key governance actors may serve specific purposes just because they are dyadic, i.e. there is an exclusion of other parties. First, our data shows that dyadic interaction can serve as an outlet for friction experienced within formal group interaction. When a CEO confidentially vents emotions with the chair after a board meeting, the fact that other board members are not present may play a key role: there can be emotional release without anyone losing face. Similarly, we propose that 
when the chair gives the CEO feedback after a board meeting, the chair can protect board members' individual views by presenting the board members' views as collective feedback. From the CEO's perspective, a one-on-one interaction when receiving feedback can also provide a more balanced setting from the power perspective. Second, our study suggests that the owners may prefer dyadic interaction over formal group interaction on personal matters and matters that represent a different logic than pure economic rationality. In these cases dyadic interaction provides emotional and relational benefits and for reaching them, it is also important also who does not participate the dyadic interaction.

The formal board meeting can be considered as a space where managerialism (Johannisson and Huse 2000) and economic rationality dominates, and formal board member roles are enacted. At such times, emotions, potential non-financial goals, and other family-related matters may be viewed as 'disruptions' that should be dealt with outside formal meetings. In other words, the smooth and professional conduct of formal board meetings is at stake. Therefore, dyadic interactions may not only serve process-oriented purposes discussed in Contribution 1 but also offer important relational and emotional benefits for those involved (and potentially for those excluded, if unwanted disruption in larger group interaction is avoided). This interpretation is linked with earlier suggestions of back-stage interaction as a way to smooth out interaction at the front-stage meetings (Graaf 2018; Johed and Catasús 2018).

As Johed and Catasús (2018, p. 369) have observed, 'an interactional ritual carries expectations about how actors should relate to each other'. Our data suggests that the emotional and relational benefits of dyadic discussions may be related to the role flexibility that dyadic interactions may encourage more than formal board meetings. While the roles of CEO, a chair, and an owner may be dominant in the provision of process-related benefits (discussed in Contribution 1), these individuals may adopt other roles when seeking the emotional and relational benefits of dyadic interaction. The chair enacts a role of a trusted partner towards the CEO and an owner that of a family member or an individual shareholder towards the CEO and the chair. This finding builds on the insights of Sievinen et al. (2020a) about the role of the family firm actors' multiple identities in the context of family firm governance. Dyadic interactions can offer a platform for assuming different roles in a more versatile way than a larger, more formal group interaction.

Our findings underline the importance of the chair in orchestrating the dyadic interaction of key governance actors. Our findings indicate that the benefits of dyadic relations for a family firm governance can exceed mere process-related benefits and the 'technical' advantages of small group interaction vis-a-vis larger group interaction (Bendersky and Hays 2012; Garg and Eisenhardt 2017). Matters that depend on non-financial rationality can be discussed, and conflicts and negative emotions have additional arenas in which to be resolved. The ability to assume different roles besides that of a board member can increase the owner and the chair's response flexibility to issues that emerge in family firm governance (Sievinen et al. 2020a). 


\section{New research avenues and implications for the practice and other stakeholders}

Considering our focus on two companies only, and the scarcity of studies on dyadic interaction in the corporate governance of family firms, we welcome further empirical research on the topic. While case studies enable the collection and investigation of detailed data, focusing on larger samples would enable replication logic. A study covering a larger sample of the CEOs, chairs and owners of family firms is needed. Also, cultural contexts that differ significantly from Nordic countries can offer further, and potentially different, insights into the dyadic dynamics between the three entities.

We consider the following questions intriguing for further research: (1) Does dyadic, back-stage interaction involve less impression management (Goffman 1959; Solomon et al. 2013) than formal board meetings? (2) What forms the basis for the actors' views on what is considered 'disruption' that needs to be dealt with outside formal board meetings? (3) To what extent, if any, are the other roles than that of a board member, enacted within the dyadic interaction by the board members, linked to the breaking the rules of what is considered 'good governance'? Furthermore, while our study is not about the advantages and disadvantages of non-family versus family member chairs, our findings on the important role of the chair in managing the informal interaction call for additional study into whether a non-family chair is differently positioned than a family-member chair to do this managing.

Also, we recommend further study on the implications of what we conceptualise as an 'Overton's window' of board work on the board's and the executives' shared understanding of the situational picture.

Our study shows practitioners that actions aimed to improve a board's decisionmaking process can be undermined if they address the formal governance process at the front-stage only. We argue that assessing the decision-making process of a firm is inadequate if it dismisses the role of dyadic interaction. As our research shows that the chair can enact much of their resource role as well as provide also emotional support in one-on-one interaction with the CEO, it could be useful to capture the quality of this relationship when assessing the performance of both the CEO and the chair. The chair and the owners, who can effectively support the CEO through their knowledge, experience and sometimes also ability to use empathy effectively, and the CEO, who can help the chair to facilitate board work through timely and accurate information provision, can be invaluable resources for a firm. Evaluating the performance of the board members and the CEO without taking these tasks into account does not necessarily capture the components contributing to high performance.

While dyadic interaction can be beneficial, our findings remind us that the chairs and the owners must always keep their influence in check so that it does not limit the healthy cognitive conflict required for efficient board decisions. In the wider context of the development of good family firm governance, we also suggest new approaches to make informal governance practices more transparent for the relevant stakeholders of a family firm. 
Open Access This article is licensed under a Creative Commons Attribution 4.0 International License, which permits use, sharing, adaptation, distribution and reproduction in any medium or format, as long as you give appropriate credit to the original author(s) and the source, provide a link to the Creative Commons licence, and indicate if changes were made. The images or other third party material in this article are included in the article's Creative Commons licence, unless indicated otherwise in a credit line to the material. If material is not included in the article's Creative Commons licence and your intended use is not permitted by statutory regulation or exceeds the permitted use, you will need to obtain permission directly from the copyright holder. To view a copy of this licence, visit http://creativecommons.org/licen ses/by/4.0/.

\section{References}

Abraham, S., \& Bamber, M. (2017). The Q\&A: under surveillance. Accounting, Organizations and Society, $58,15-31$.

Ahrens, T., \& Khalifa, R. (2013). Researching the lived experience of corporate governance. Qualitative Research in Accounting and Management, 10(1), 4-30.

Astrachan, J. H. (2010). Strategy in family business: Toward a multidimensional research agenda. Journal of Family Business Strategy, 1(1), 6-14.

Bagehot, W. (1867). The English constitution. London: Chapman \& Hall.

Bankewitz, M. (2016). Boards' different advisory tasks-what makes board members use their knowledge? American Journal of Management, 16(1), 54-69.

Bankewitz, M. (2018). Board advisory tasks: The importance to differentiate between functional and firm-specific advice. European Management Review, 15(4), 521-539.

Barroso-Castro, C., Villegas-Periñan, M. M., \& Dominguez, M. (2017). Board members' contribution to strategy: The mediating role of board internal processes. European Research on Management and Business Economics, 23(2), 82-89.

Bendersky, C., \& Hays, N. A. (2012). Status conflict in groups. Organization Science, 23(2), 323-340.

Bettinelli, C. (2011). Board of directors in family firms: An exploratory study of structure and group process. Family Business Review, 24(2), 151-169.

Bezemer, P., Nicholson, G., \& Pugliese, A. (2018). The influence of board chairs on director engagement: A case-based exploration of boardroom decision-making. Corporate Governance: An International Review, 26(3), 219-234.

Brunninge, O., Nordqvist, M., \& Wiklund, J. (2007). Corporate governance and strategic change in SMEs: The effects of ownership, board composition and top management teams. Small Business Economics, 29(3), 295-308.

Cadbury, A. (1992). The financial aspects of corporate governance: Report of the committee on the Financial Aspects of Corporate Governance. London: Gee \& Co.

Canterino, F., Cirella, S., Guerci, M., Shani, A. B., \& Brunelli, M. S. (2013). Leading transformation in a family-owned business: Insights from an Italian company. International Journal of Entrepreneurship and Innovation Management, 17(1-3), 54-83.

Carpenter, M. A., \& Westphal, J. D. (2001). The strategic context of external network ties: Examining the impact of director appointments on board involvement in strategic decision making. Academy of Management Journal, 44(4), 639-660.

Cater, J., \& Schwab, A. (2008). Turnaround strategies in established small family firms. Family Business Review, 21(1), 31-50.

Chrisman, J. J., Chua, J. H., Isabelle, L.-M., Miller, D., \& Steier, L. P. (2018). Governance mechanisms and family firms. Entrepreneurship Theory and Practice, 42(2), 171-186.

Chua, J. H., Chrisman, J. J., \& Sharma, P. (1999). Defining the family business by behavior. Entrepreneurship Theory and Practice, 23(4), 19-39.

Daspit, J. J., Chrisman, J. J., Sharma, P., Pearson, A. W., \& Mahto, R. V. (2018). Governance as a source of family firm heterogeneity. Journal of Business Research, 84, 293-300.

Finkelstein, S. (1992). Power in top management teams: Dimensions, measurement, and validation. Academy of Management Journal, 35(3), 505-538.

Finkelstein, S., \& Mooney, A. C. (2003). Not the usual suspects: How to use board process to make boards better. Academy of Management Perspectives, 17(2), 101-113. 
Forbes, D. P., \& Milliken, F. J. (1999). Cognition and corporate governance: Understanding boards of directors as strategic decision-making groups. Academy of Management Review, 24(3), 489-505.

Gabrielsson, J., \& Huse, M. (2002). The venture capitalist and the board of directors in SMEs: Roles and processes. Venture Capital: An International Journal of Entrepreneurial Finance, 4(2), 125-146.

Garg, S., \& Eisenhardt, K. M. (2017). Unpacking the CEO-board relationship: How strategy making happens in entrepreneurial firms. Academy of Management Journal, 60(5), 1828-1858.

Gersick, K. E., Davis, J. A., Hampton, M. M., \& Lansberg, I. (1997). Generation to generation. Life cycles of the family business. Harvard: Harvard Business School Press.

Gioia, D. A., Corley, K. G., \& Hamilton, A. L. (2013). Seeking qualitative rigor in inductive research: Notes on the Gioia methodology. Organizational Research Methods, 16(1), 15-31.

Goffman, E. (1959). The presentation of self in everyday life. London: Penguin Books.

Goffman, E. (1961). Encounters: Two studies in the sociology of interaction. Indianapolis: Bobbs-Merrill.

Goffman, E. (1974). Frame analysis: An essay on the organization of experience. Harvard: Harvard University Press.

Gopinath, C., Siciliano, J. I., \& Murray, R. L. (1994). Changing role of the board of directors: In search of a new strategic identity? The Mid-Atlantic Journal of Business, 30(2), 175-185.

Graaf, J. (2018). Equity market interactions: Exploring analysts' role performances at earnings presentations. Accounting, Auditing, \& Accountability, 31(4), 1230-1256.

Hass, W. J., \& Pryor, S. G. (2005). The board's role in corporate renewal. Journal of Private Equity, 8(2), $12-19$.

Huse, M. (1998). Researching the dynamics of board-stakeholder relations. Long Range Planning, 31(2), 218-226.

Huse, M. (2005). Accountability and creating accountability: A framework for exploring behavioural perspectives of corporate governance. British Journal of Management, 16, S65-S79.

Huse, M. (2007). Boards, governance and value creation. Cambridge: Cambridge University Press.

Huse, M., \& Zattoni, A. (2008). Trust, firm life cycle, and actual board behavior: Evidence from" one of the lads" in the board of three small firms. International Studies of Management \& Organization, 38(3), 71-97.

Imam, S., \& Spence, C. (2016). Context, not predictions: A field study of financial analysts. Accounting, Auditing \& Accountability Journal, 29(2), 226-247.

Johannisson, B., \& Huse, M. (2000). Recruiting outside board members in the small family business: An ideological challenge. Entrepreneurship \& Regional Development, 12(4), 353-378.

Johed, G., \& Catasús, B. (2018). Auditor face-work at the annual general meeting. Contemporary Accounting Research, 35(1), 365-393.

Karra, N., Tracey, P., \& Phillips, N. (2006). Altruism and agency in the family firm: exploring the role of family, kinship, and ethnicity. Entrepreneurship: Theory \& Practice, 30(6), 861-877.

Kenny, D. A., Kashy, D. A., \& Cook, W. L. (2006). Dyadic data analysis. New York: Guilford Press.

Koskinen, S., \& Lämsä, A.-M. (2016). The CEO-chair relationship from a relational leadership perspective. Leadership \& Organization Development Journal, 37(8), 1135-1146.

Koskinen, S., \& Lämsä, A.-M. (2017). Development of trust in the CEO-chair relationship. Baltic Journal of Management, 12(3), 274-291.

Kotlar, J., \& De Massis, A. (2013). Goal setting in family firms: Goal diversity, social interactions, and collective commitment to family-centered goals. Entrepreneurship Theory and Practice, 37(6), 1263-1288.

Leblanc, R., \& Schwartz, M. S. (2007). The black box of board process: Gaining access to a difficult subject. Corporate Governance: An International Review, 15(5), 843-851.

Liden, R. C., Anand, S., \& Vidyarthi, P. (2016). Dyadic relationships. Annual Review of Organizational Psychology and Organizational Behavior, 3, 139-166.

Mace, M. L. (1971). Directors: Myths and realities. Boston, MA: Harvard University.

March, J. G. (1994). A primer on decision making: How decisions happen. New York: Free Press.

March, J. G., \& Olsen, J. P. (1989). Rediscovering institutions: The organizational base of politics. New York: Free Press.

McNulty, T., \& Pettigrew, A. (1999). Strategists on the board. Organization Studies, 20(1), 47-74.

McNulty, T., Pettigrew, A., Jobome, G., \& Morris, C. (2011). The role, power and influence of company chairs. Journal of Management \& Governance, 15(1), 91-121.

Mustakallio, M., Autio, E., \& Zahra, S. A. (2002). Relational and contractual governance in family firms: Effects on strategic decision making. Family Business Review, 15(3), 205-222. 
Nag, R., \& Gioia, D. A. (2012). From common to uncommon knowledge: Foundations of firm-specific use of knowledge as a resource. Academy of Management Journal, 55(2), 421-457.

Nordstrom, O., \& Jennings, J. E. (2018). Looking in the other direction: An ethnographic analysis of how family businesses can be operated to enhance familial well-being. Entrepreneurship Theory and Practice, 42(2), 317-339.

Ocasio, W. (1999). Institutionalized action and corporate governance: The reliance on rules of CEO succession. Administrative Science Quarterly, 44(2), 384-416.

Pettigrew, A. M. (1990). Studying strategic choice and strategic change. A comment on Mintzberg and Waters: "Does decision get in the way?" Organization Studies, 11(1), 6-11.

Pettigrew, A., \& McNulty, T. (1995). Power and influence in and around the boardroom. Human Relations, 48(8), 845-873.

Roberts, J. (2002). Building the complementary board. The work of the plc chairman. Long Range Planning, 35(5), 493-520.

Roberts, J., \& Stiles, P. (1999). The relationship between chairmen and chief executives: Competitive or complementary Roles? Long Range Planning, 32(1), 36-48.

Roberts, J., McNulty, T., \& Stiles, P. (2005). Beyond agency conceptions of the work of the non-executive director: Creating accountability in the boardroom. British Journal of Management, 16, S5-S26.

Roberts, J., Sanderson, P., Barker, R., \& Hendry, J. (2006). In the mirror of the market: The disciplinary effects of company/fund manager meetings. Accounting, Organizations and Society, 31(3), 277-294.

Siebels, J. F., \& zu Knyphausen-Aufseß, D. (2012). A review of theory in family business research: The implications for corporate governance. International Journal of Management Reviews, 14(3), 280-304.

Sievinen, H. M., Ikäheimonen, T., \& Pihkala, T. (2019). The advisory role of non-family board members: A case-based study of a family firm. Journal of Management and Governance, 24, 871-903.

Sievinen, H. M., Ikäheimonen, T., \& Pihkala, T. (2020a). Owners' rule-based decision-making in family firm strategic renewal. Scandinavian Journal of Management, 36(3), 101119.

Sievinen, H. M., Ikäheimonen, T., \& Pihkala, T. (2020b). Strategic renewal in a mature family-owned company-A resource role of the owners. Long Range Planning, 53(2), 101864.

Sinani, E., Stafsudd, A., Thomsen, S., Edling, C., \& Randøy, T. (2008). Corporate governance in Scandinavia: Comparing networks and formal institutions. European Management Review, 5(1), $27-40$.

Solomon, J. F., \& Darby, L. (2005). Is private social, ethical and environmental reporting mythicizing or demythologizing reality? Accounting Forum, 29(1), 27-47.

Solomon, J. F., Solomon, A., Joseph, N. L., \& Norton, S. D. (2013). Impression management, myth creation and fabrication in private social and environmental reporting: Insights from Erving Goffman. Accounting, Organizations and Society, 38(3), 195-213.

Sparrowe, R. T., \& Liden, R. C. (1997). Process and structure in leader-member exchange. Academy of management Review, 22(2), 522-552.

Steier, L. (2001). Family firms, plural forms of governance, and the evolving role of trust. Family Business Review, 14(4), 353-368.

Stevenson, W. B., \& Radin, R. F. (2009). Social capital and social influence on the board of directors. Journal of Management Studies, 46(1), 16-44.

Vaivio, J. (2006). The accounting of 'the meeting': Examining calculability within a 'fluid' local space. Accounting, Organizations and Society, 31(8), 735-762.

Vardaman J.M., Allen, D.G., \& Rogers B.L. (2018). We are friends but are we family? Organizational identification and nonfamily employee turnover. Entrepreneurship Theory and Practice, 42(2), 290-309.

Westphal, J. D., \& Bednar, M. K. (2005). Pluralistic ignorance in corporate boards and firms' strategic persistence in response to low firm performance. Administrative Science Quarterly, 50(2), 262-298.

Westphal, J. D., \& Graebner, M. E. (2010). A matter of appearances: How corporate leaders manage the impressions of financial analysts about the conduct of their boards. Academy of Management Journal, 53(1), 15-44.

Westphal, J. D., \& Stern, I. (2006). The other pathway to the boardroom: Interpersonal influence behavior as a substitute for elite credentials and majority status in obtaining board appointments. Administrative Science Quarterly, 51(2), 169-204.

Westphal, J. D., \& Zajac, E. J. (1995). Who shall govern? CEO/board power, demographic similarity, and new director selection. Administrative Science Quarterly, 40(1), 60-83.

Westphal, J. D., \& Zajac, E. J. (1998). The symbolic management of stockholders: Corporate governance reforms and shareholder reactions. Administrative Science Quarterly, 43, 127-153. 
Westphal, J. D., \& Zajac, E. J. (2013). A behavioral theory of corporate governance: Explicating the mechanisms of socially situated and socially constituted agency. Academy of Management Annals, $7(1), 607-661$.

Zhou, X. (1993). The dynamics of organizational rules. American Journal of Sociology, 98(5), 1094-1133.

Publisher's Note Springer Nature remains neutral with regard to jurisdictional claims in published maps and institutional affiliations. 